\title{
Endoparasites of capybaras (Hydrochoerus hydrochaeris) from anthropized and natural areas of Brazil
}

\author{
Endoparasitas de capivaras (Hydrochoerus hydrochaeris) provenientes de áreas \\ antropizadas e de áreas naturais do Brasil
}

\begin{abstract}
Silvio Luís Pereira de Souza1* (1); Hector Ribeiro Benatti'; Hermes Ribeiro Luz',2; Francisco Borges Costa ${ }^{1,3}$; Richard de Campos Pacheco4; Marcelo Bahia Labruna ${ }^{1}$
\end{abstract}

\begin{abstract}
'Departamento de Medicina Veterinária Preventiva e Saúde Animal, Faculdade de Medicina Veterinária e Zootecnia, Universidade de São Paulo - USP, São Paulo, SP, Brasil

${ }^{2}$ Departamento de Patologia, Programa de Pós-graduação em Biotecnologia do Renorbio, Ponto Focal Maranhão, Universidade Federal do Maranhão - UFMA, São Luís, MA, Brasil

${ }^{3}$ Departamento de Patologia, Faculdade de Medicina Veterinária, Universidade Estadual do Maranhão - UEMA, São Luís, MA, Brasil

${ }^{4}$ Programa de Pós-graduação em Ciências Veterinárias, Faculdade de Medicina Veterinária, Universidade Federal de Mato Grosso, Cuiabá, MT, Brasil
\end{abstract}

How to cite: Souza SLP, Benatti HR, Luz HR, Costa FB, Pacheco RC, Labruna MB. Endoparasites of capybaras (Hydrochoerus hydrochaeris) from anthropized and natural areas of Brazil. Braz J Vet Parasitol 2021; 30(2): e027420. https://doi.org/10.1590/ S1984-29612021049

\begin{abstract}
This study aimed to evaluate the occurrence of endoparasites in fecal samples of capybaras from anthropized areas in seven cities in the state of São Paulo, southeastern Brazil, and natural areas in two locations in the Pantanal biome. For the parasitological evaluation of samples, feces were subjected to centrifugal sedimentation in water-ether and centrifugal flotation in sucrose solution. Out of the 113 samples examined, $97.3 \%(110 / 113)$ were positive for the presence of helminth eggs and/or protozoan oocysts, with 96.7\% (89/92) and 100\% (21/21) in capybaras from anthropized and natural areas, respectively. Helminth eggs belonging to the Class Cestoda (Monoecocestus spp.), Class Digenea, and Class Nematoda (Trichostrongyloidea, Strongyloides chapini, Protozoophaga obesa, and Capillaria hydrochoeri) were detected. Coccidia oocysts of Eimeria spp. and Cryptosporidium spp. were detected. The difference found was in the occurrence of S. chapini between anthropized and natural areas, as S. chapini was not detected in natural areas. Capybaras from anthropized areas showed a greater species richness of endoparasites, including species such as Fasciola hepatica and Cryptosporidium spp., that might have zoonotic potential.
\end{abstract}

Keywords: Capybara, helminths, protozoa, parasites.

\section{Resumo}

O presente estudo apresentou como objetivo avaliar a ocorrência de endoparasitas nas amostras de fezes de capivaras de áreas antropizadas de sete cidades do Estado de São Paulo, Sudeste do Brasil, e áreas naturais de duas localidades do bioma Pantanal. Para a avaliação parasitológica das amostras de fezes foram empregadas as técnicas de centrífugo-sedimentação em água-éter e centrífugo-flutuação em solução de sacarose. De um total de 113 amostras examinadas, 97,3\% (110/113) apresentaram resultados positivos para a presença de ovos de helmintos e/ou oocistos de protozoários. No geral, a positividade foi de 96,7\% (89/92), e 100\% (21/21) em capivaras de áreas antropizadas e naturais, respectivamente. Foram detectados ovos de helmintos pertencentes às Classes Cestoda (Monoecocestus spp.), Digenea e Nematoda (Trichostrongyloidea, Strongyloides chapini, Protozoophaga obesa e Capillaria hydrochoeri). Em relação aos protozoários, foram detectados oocistos dos coccídios Eimeria spp. e Cryptosporidium spp. A diferença encontrada foi na comparação da ocorrência de S. chapini em áreas antropizadas e naturais, sem detecção para esta última área. As capivaras provenientes das áreas antropizadas apresentaram uma maior riqueza de espécies de endoparasitas, incluindo as espécies Fasciola hepatica e Cryptosporidium spp., que podem apresentar potencial zoonótico.

Palavras-chave: Capivaras, helmintos, protozoários, parasitas. 


\section{Introduction}

The capybara (Hydrochoerus hydrochaeris) is considered the largest rodent in the world. It is native to Brazil and is widely distributed in South America (Alho, 1986; Vargas et al., 2007) and prefers warm environments with water bodies, areas for grazing and forest fragments, which provide refuges as well as shelters for parturition and protection against predators (Alho, 1986; Rodrigues et al., 2013).

Anthropic factors include the expansion of human activities over habitats originally occupied by native fauna, such as capybaras. The cutting of native forest for the formation of pastures or crops promotes the growth of capybara populations because natural predators are free from such habitats and capybaras have a high reproductive potential (Vargas et al., 2007; Rodrigues et al., 2013). Anthropized areas often feature large numbers of capybaras that cause agricultural damage; consequently, capybaras are often considered pests and pose public health and safety risks (Vargas et al., 2007; Rodrigues et al., 2013). The increase in capybara populations in anthropized areas results in the increased contact of these animals with the human population and domestic livestock (Ribeiro et al., 2010).

Capybaras are host to a variety of pathogens of public health importance, such as the bacteria Rickettsia rickettsii (Souza et al., 2009; Polo et al., 2018) and Leptospira interrogans (Gioia-Di Chiacchio et al., 2014); the protozoa Trypanosoma spp. (Muñoz \& Chávez, 2001; Valadas et al., 2010), Toxoplasma gondii (Yai et al., 2009), Cryptosporidium parvum (Meireles et al., 2007), and Giardia spp. (Reginatto et al., 2008); and the helminth F. hepatica (Labruna et al., 2018).

In addition, previous studies have documented several gastrointestinal endoparasites that can affect capybara populations, especially helminths and coccidian protozoa. Among helminths, nematodes that have been previously documented include Viannella hydrochoeri, Hydrochoerisnema anomalobursata, Trichostrongylus axei, S. chapini, C. hydrochoeri, Trichuris sp., and P. obesa. Documented cestodes include Monoecocestus hagmanni, Monoecocestus macrobursatum, Monoecocestus hydrochoeri and Monoecocestus jacobi, and documented digeneans include Hippocrepis hippocrepis, Taxorchis schistocotyle, Hydrochoeristrema cabrali, Neocotyle neocotyle, Nudacotyle valdevaginatus, N. tertius, and F. hepatica. In relation to protozoa, it has been reported Giardia spp., Balantidium coli, Eimeria spp., and C. parvum (Casas et al., 1995; Bonuti et al., 2002; Meireles et al., 2007; Reginatto et al., 2008; Sinkoc et al., 2009, Corriale et al., 2011; Labruna et al., 2018).

For epidemiological studies and routine laboratory diagnosis of endoparasites in populations of wild animals, mainly rare and endangered species, there is a growing demand to encourage the use of noninvasive methods (Solórzano-García \& Pérez-Ponce de León, 2017). Parasitological analyses of feces might provide an important methodological alternative (Vieira et al., 2006), as such analyses permit rapid diagnoses and allow a large number of samples to be easily assessed (Brandão et al., 2009).

Most epidemiological studies using parasitological analyses of feces to study endoparasites are based on samples from a single location or population of capybaras in public parks (El-Kouba et al., 2008; Truppel, 2009; Gioia-Di Chiacchio et al., 2014) or captive animals (Gurgel et al., 2007; Santos et al., 2011; Reginatto et al., 2008). These studies thus do not capture the effect of different environments on the parasitic diversity in animals.

Given the lack of comprehensive epidemiological studies, the aim of this study was to evaluate and to compare the occurrence of endoparasites in the fecal samples of capybaras from anthropized areas in seven cities in the state of São Paulo, southeastern Brazil, and natural areas in two locations in the Pantanal biome.

\section{Materials and Methods}

The capybaras sampled in this study were from anthropized areas in the state of São Paulo and from natural areas of the Pantanal biome, as described by Luz et al. (2019). Anthropized areas sampled were environments modified by human activities and were located in the municipalities of Americana, Araras, Avaré, Piracicaba, Pirassununga, Ribeirão Preto and Tatuí in the state of São Paulo. The natural areas were environments that have not been altered by human activities and consisted of two locations in the Pantanal biome: Poconé in the state of Mato Grosso and Corumbá in the state of Mato Grosso do Sul.

Animals were collected between 2015 and 2018 following the methods of Luz et al. (2019). Fecal samples were collected directly from the rectum of captured capybaras, packed in plastic containers, and kept refrigerated at $4{ }^{\circ} \mathrm{C}$ until they were brought to the laboratory. Centrifugal sedimentation in water-ether (Ferreira et al., 1962) and centrifugal flotation in sucrose solution (Ogassawara \& Benassi, 1980) were used for parasitological evaluations. The eggs and oocysts of the parasites in capybara feces were identified morphologically based on Faust (1935), Casas et al. (1995), Thienpont et al. (2003), Monteiro (2011), and Dracz et al. (2016). In some cases, the structures were measured using Image-Pro Plus 5.1 for the analysis of images and morphometry fitted to an Olympus microscope. 
The proportions of capybaras containing eggs or oocysts of each of the identified parasites were compared between anthropic and natural areas by chi-square tests. Analyses were performed using the program Minitab ${ }^{\circledR}$ Release 18; differences were considered significant when $P<0.05$.

This study was approved by the Institutional Animal Care and Use Committee (IACUC) of the Faculty of Veterinary Medicine of the University of São Paulo (approval number 5948070314) and was carried out in accordance with the regulations/guidelines of the Brazilian National Council of Animal Experimentation (CONCEA). Field captures of capybaras were authorized by the Brazilian Ministry of the Environment (permit SISBIO Nos. 43259-6) and by the São Paulo Forestry Institute (Cotec permit 260108-000.409/2015).

\section{Results}

Results of the evaluation of fecal samples from capybaras from the anthropized areas of the state of São Paulo and from natural areas of the Pantanal biome are detailed in Table 1.

Overall, a total of 113 samples were evaluated, and 97.3\% (110/113) had helminth eggs and/or protozoan oocysts: $96.7 \%$ (89/92) and 100\% (21/21) in anthropized and in natural areas, respectively.

Table 1. Occurrence of endoparasites in fecal samples of capybaras (Hydrochoerus hydrochaeris) from anthropized areas of the state of São Paulo and from natural areas of the Pantanal, Brazil.

\begin{tabular}{|c|c|c|c|c|c|c|c|c|c|c|}
\hline \multirow[b]{4}{*}{ Localities } & \multirow[b]{4}{*}{$\begin{array}{l}\text { Number of } \\
\text { capybaras }\end{array}$} & \multicolumn{9}{|c|}{ Number of capybara feces containing each of the identified parasites } \\
\hline & & \multicolumn{7}{|c|}{ Helminths } & \multirow{2}{*}{\multicolumn{2}{|c|}{$\frac{\text { Protozoa }}{\text { Subclass: Coccidia }}$}} \\
\hline & & \multicolumn{4}{|c|}{ Class: Nematoda } & \multirow{2}{*}{ 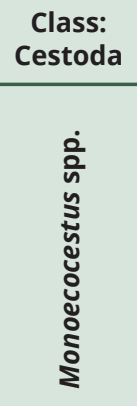 } & \multicolumn{2}{|c|}{ Class: Digenea } & & \\
\hline & & 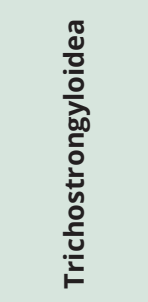 & 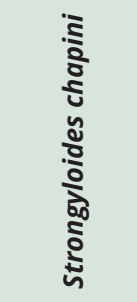 & 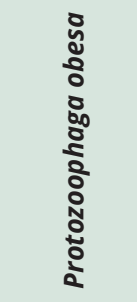 & 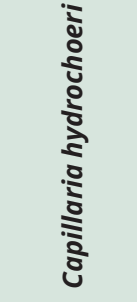 & & 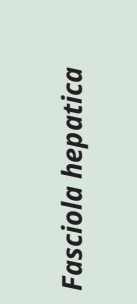 & 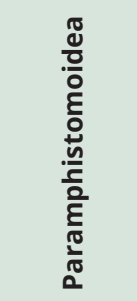 & $\begin{array}{l}\frac{0}{0} \\
\text { n } \\
\stackrel{0}{\Delta} \\
\stackrel{\Sigma}{\mathbf{s}}\end{array}$ & 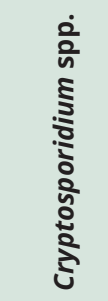 \\
\hline \multicolumn{11}{|l|}{ ANTHROPIC AREAS } \\
\hline Americana - SP & 09 & 08 & 03 & 05 & 0 & 0 & 0 & 0 & 04 & 0 \\
\hline Araras - SP & 03 & 02 & 01 & 0 & 02 & 0 & 0 & 0 & 03 & 0 \\
\hline Avaré - SP & 14 & 06 & 03 & 03 & 01 & 07 & 0 & 0 & 11 & 0 \\
\hline Piracicaba - SP & 11 & 09 & 03 & 04 & 02 & 0 & 01 & 0 & 11 & 0 \\
\hline Pirassununga - SP & 16 & 05 & 01 & 03 & 02 & 01 & 0 & 0 & 12 & 0 \\
\hline Ribeirão Preto - SP & 29 & 14 & 13 & 16 & 07 & 05 & 0 & 0 & 21 & 01 \\
\hline Tatuí - SP & 10 & 06 & 05 & 08 & 07 & 01 & 01 & 02 & 06 & 0 \\
\hline $\begin{array}{l}\text { Total anthropic } \\
\text { areas ( } \% \text { positive)* }\end{array}$ & 92 & $\begin{array}{c}50 \\
(54.3 \%) a\end{array}$ & $\begin{array}{c}29 \\
(31.5 \%) a\end{array}$ & $\begin{array}{c}39 \\
(42.3 \%) a\end{array}$ & $\begin{array}{c}21 \\
(22.8 \%) a\end{array}$ & $\begin{array}{c}14 \\
(15.2 \%) a\end{array}$ & $\begin{array}{c}02 \\
(2.17 \%) a\end{array}$ & $\begin{array}{c}02 \\
(2.17 \%) a\end{array}$ & $\begin{array}{c}68 \\
(73.9 \%) a\end{array}$ & $\begin{array}{c}01 \\
(1.1 \%) \mathrm{a}\end{array}$ \\
\hline \multicolumn{11}{|l|}{ NATURAL AREAS } \\
\hline Poconé - MT & 12 & 05 & 0 & 02 & 0 & 02 & 0 & 0 & 11 & 0 \\
\hline Corumbá - MS & 09 & 05 & 0 & 03 & 01 & 03 & 0 & 0 & 07 & 0 \\
\hline $\begin{array}{l}\text { Total natural areas } \\
\text { (\% positive)* }\end{array}$ & 21 & $\begin{array}{c}10 \\
(47.6 \%) a\end{array}$ & $\begin{array}{c}0 \\
(0 \%) b\end{array}$ & $\begin{array}{c}05 \\
(23.8 \%) a\end{array}$ & $\begin{array}{c}01 \\
(4.7 \%) a\end{array}$ & $\begin{array}{c}05 \\
(23.8 \%) a\end{array}$ & $\begin{array}{c}0 \\
(0 \%) a\end{array}$ & $\begin{array}{c}0 \\
(0 \%) a\end{array}$ & $\begin{array}{c}18 \\
(85.7 \%) a\end{array}$ & $\begin{array}{c}0 \\
(0 \%) a\end{array}$ \\
\hline TOTAL (\% positive) & 113 & $\begin{array}{c}60 \\
(53.1 \%)\end{array}$ & $\begin{array}{c}29 \\
(25.6 \%)\end{array}$ & $\begin{array}{c}44 \\
(38 \%)\end{array}$ & $\begin{array}{c}22 \\
(19.4 \%)\end{array}$ & $\begin{array}{c}19 \\
(16.8 \%)\end{array}$ & $\begin{array}{c}02 \\
(1.7 \%)\end{array}$ & $\begin{array}{c}02 \\
(1.7 \%)\end{array}$ & $\begin{array}{c}86 \\
(76.1 \%)\end{array}$ & $\begin{array}{c}01 \\
(0.8 \%)\end{array}$ \\
\hline
\end{tabular}

* Values on the same column followed by different letters are significantly different between anthropic and natural areas $(P<0.05)$. 
Helminth eggs belonging to the Class Cestoda (Monoecocestus spp.), Class Digenea and Class Nematoda (Trichostrongyloidea, S. chapini, P. obesa and C. hydrochoeri) were detected. Coccidia oocysts of the protozoa Eimeria spp. and Cryptosporidium spp. were detected.

Eggs belonging to the superfamily Trichostrongyloidea were more frequently detected in samples from both of the studied areas $(53.1 \%(60 / 113))$. We detected parasitism by P. obesa in $38 \%(44 / 113)$ of samples, S. chapini in $25.6 \%$ (29/113), C. hydrochoeri in 19.4\% (22/113), Monoecocestus spp. in 16.8\% (19/113), Paramphistomoidea and F. hepatica in 1.7\% (2/113), the latter of which was found in only two locations in anthropized areas (Table 1).

The only statistical difference observed in the occurrence of an endoparasite between natural and anthropized areas was for S. chapini, which was identified only in capybaras from anthropized areas (Table 1).

The oocysts of Eimeria spp. were detected in 76.1\% (86/113) of the samples and were found in all locations in the natural and anthropized areas of the study. Cryptosporidium spp. was detected in a single sample from the anthropized area (Ribeirão Preto).

Capybaras from anthropized areas had a greater species richness of endoparasites, especially $F$. hepatica and Cryptosporidium spp., which may have zoonotic potential. Some of the eggs and oocysts in capybara fecal samples are shown in Figure 1.
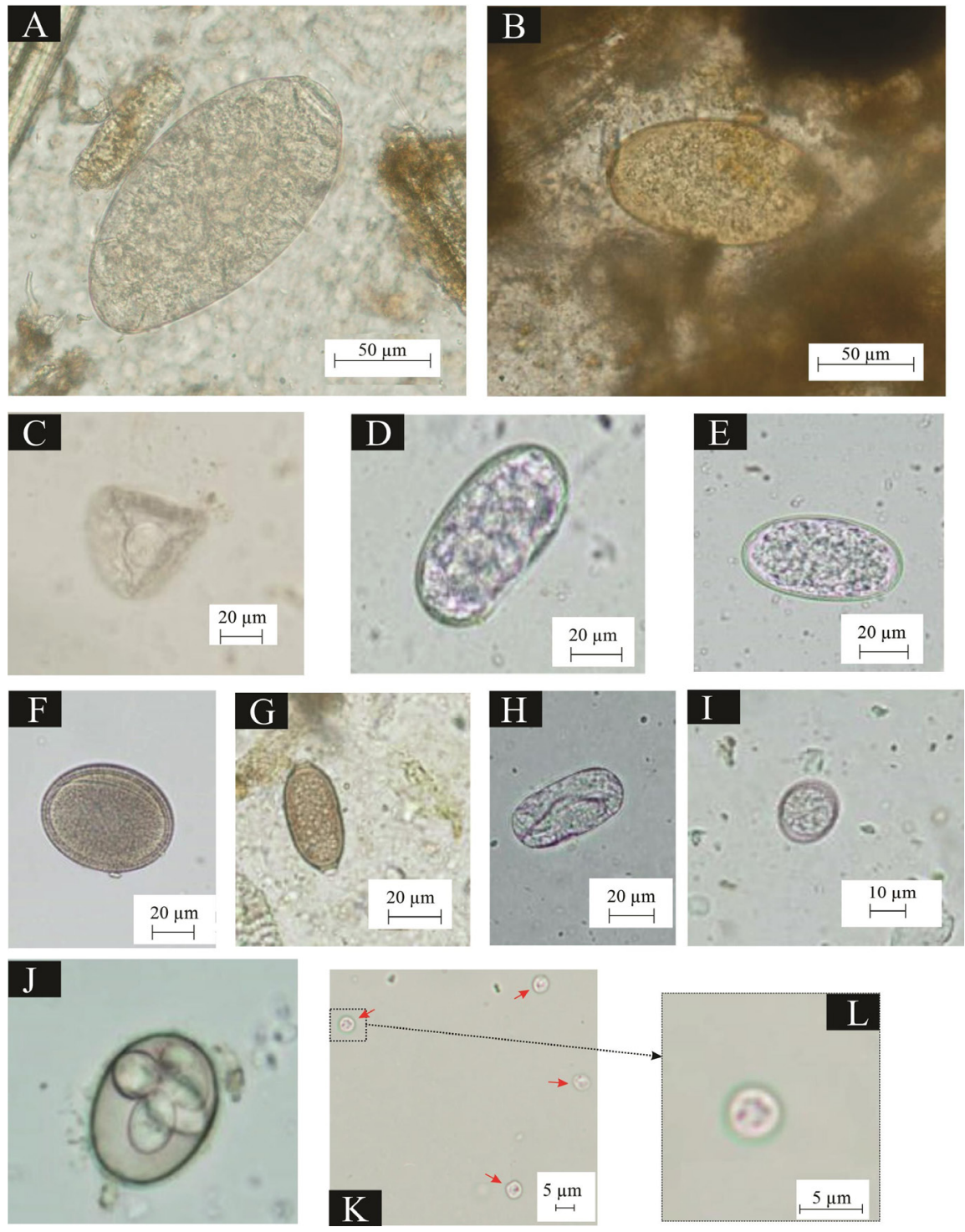

Figure 1. Eggs and oocysts found in capybara fecal samples from anthropized areas of the state of São Paulo and from natural areas of the Pantanal biome, Brazil. (400× magnification). Digenea eggs: (A) Paramphistomoidea and (B) Fasciola hepatica. Cestode eggs: (C) Monoecocestus spp. Nematode eggs: (D-E) Trichostrongyloidea; (F) Protozoophaga obesa; (G) Capillaria hydrochoeri; and (H) Strongyloides chapini. Coccidia oocysts: (I) Eimeria spp.; (J) Eimeria spp. sporulated (1000× magnification); (K-L) Cryptosporidium spp. 


\section{Discussion}

In this study, 113 fecal samples from capybaras were evaluated. To our knowledge, this is the first study to compare the species richness of gastrointestinal endoparasites in a population of capybaras in anthropized and natural areas with samples from more than 100 wild animals.

We detected the presence of helminths and coccidian protozoa in $97.3 \%$ of the sampled capybaras. This high prevalence and diversity of endoparasites might stem from the gregarious, amphibious and territorial behavior of these mammals; in addition, their habit of grazing close to the ground might facilitate the ingestion of eggs and larvae (Truppel, 2009; Gioia-Di Chiacchio et al., 2014).

Eggs from nematodes belonging to the superfamily Trichostrongyloidea were detected in capybaras from both areas. The parasites (Trichostrongyloidea, Viannaiidae) $V$. hydrochoeri and $H$. anomalobursata are specific to capybaras. The nematode $V$. hydrochoeri might be particularly widespread given that it is commonly reported in necropsy studies that have been conducted in various regions of Brazil and in other South American countries, reaching as high as 100\% of capybara samples (Costa \& Catto, 1994; Bonuti et al., 2002; Salas \& Herrera, 2004; Sinkoc et al., 2004).

Although $\mathrm{H}$. anomalobursata was identified in $90 \%$ of capybaras evaluated by necropsy in the Pantanal (Bonuti et al., 2002) and in 58.3\% in a study of the Taim Ecological Reserve in southern Brazil (Sinkoc et al., 2009), several studies based on necropsy did not detect it, indicating that this nematode does not have a wide distribution across all regions (Costa \& Catto, 1994; Salas \& Herrera, 2004; Sinkoc et al., 2004).

Although the eggs of parasites belonging to the superfamily Trichostrongyloidea have similar morphological characteristics, which make accurate identification to genus or species of the agents involved in the infection impossible, necropsy studies point out that $V$. hydrochoeri is the most likely Trichostrongyloidea parasite affecting capybaras in both natural and anthropized areas (Costa \& Catto, 1994; Bonuti et al., 2002; Salas \& Herrera, 2004; Sinkoc et al., 2004).

The occurrence of other nematodes (Trichostrongyloidea, Trychostrongylidae), such as Trichostrongylus axei, Haemonchus sp. and Cooperia spp., is rare and often considered accidental (Sinkoc et al., 2009). Infection of capybaras by these parasites usually occurs in anthropized areas and requires interaction with other livestock species, such as cattle, goats, sheep and horses.

Ellipsoid larvated eggs were detected in this study and were consistent with the morphological and biometric description of Vieira et al. (2006) for S. chapini, the only species of this genus that is known to parasitize capybaras. Young animals are more susceptible to parasitism (Costa \& Catto, 1994), and severe clinical manifestations have been observed in individuals bred in captivity (Pinheiro et al., 2006; Santos et al., 2011). Eggs of S. chapini were only detected in stool samples of capybaras from anthropized areas. Other studies that have collected stool samples of capybaras from anthropized areas such as public parks reported occurrences of this parasite ranging from 0 to 56\% (El-Kouba et al., 2008; Truppel, 2009; Gioia-Di Chiacchio et al., 2014); results from this study were similar to those obtained from captive samples (Santos et al., 2011). The high variation observed for capybaras sampled from anthropized areas may stem from the large number of samples from pups collected in these areas; in contrast, a smaller number of samples from pups was collected from natural areas.

Necropsy studies have revealed that the oxyurid $P$. obesa had a high occurrence and intensity of infection and affected approximately $100 \%$ of capybaras (Bonuti et al., 2002; Salas \& Herrera, 2004; Sinkoc et al., 2009); it can be easily detected in wild populations of capybaras in natural areas (Costa \& Catto, 1994; Bonuti et al., 2002), anthropized areas (Truppel, 2009; Gioia-Di Chiacchio et al., 2014) and in captive-bred individuals (Sinkoc et al., 2004). Because female parasites are eliminated in feces along with a large number of eggs, they clump externally in the form of a cluster (Ribeiro \& Amato, 2003), permitting many eggs to be simultaneously ingested (Sinkoc et al., 2004).

Helminthological surveys conducted during the previous decades using animal necropsies have shown that the nematode Capillaria hydrochoeri is the only species of this genus that parasitizes capybaras (Costa \& Catto, 1994; Bonuti et al., 2002; Sinkoc et al., 2004; 2009) and can be found in natural (Costa \& Catto, 1994; Bonuti et al., 2002) and anthropized areas (El-Kouba et al., 2008; Truppel, 2009). The ability of the eggs of this nematode to persist in the environment for several months may lead to gradual infections of capybaras that progress with age, resulting in a greater occurrence in adult animals. The tendency of capybaras to feed close to the ground and their coprophagic habits facilitate the ingestion of eggs and infectious parasites (Alho, 1986; Ribeiro \& Amato, 2003).

Capybaras can be specifically affected by cestodes belonging to the family Anoplocephalidae, especially the genus Monoecocestus. Previous necropsies of capybaras identified the following species: M. hydrochoeri, M. hagmanni, 
M. macrobursatum, and M. jacobi (Rego, 1961; Sinkoc et al., 2009). The cestodes of the family Anoplocephalidae use oribatid mites as intermediate hosts for the development of cysticercoid larvae. As these mites are found in superficial layers of the soil in vegetation and pastures (Monteiro, 2011), several environments are conducive to the development of the biological cycle of these cestodes in wild capybaras in natural areas (Costa \& Catto, 1994; Bonuti et al., 2002), anthropized areas (Truppel, 2009) or in captive capybaras (Sinkoc et al., 2004).

In samples of capybaras from anthropized areas, digenetic eggs belonging to the species F. hepatica (Monteiro, 2011; Dracz et al., 2016) and eggs with characteristics consistent with the digenetics of the Paramphistomoidea superfamily were detected (Faust, 1935; Thienpont et al., 2003; Tantaleán et al., 2012).

Parasites belonging to the Paramphistomoidea superfamily documented in studies based on necropsies of capybara populations were Taxorchis schistocotyle and Hydrochoeristrema cabrali, both of which were considered specific to capybaras (Sinkoc et al., 1998; Avelar et al., 2015); furthermore, their occurrence was directly related to the presence of mollusks that act as intermediate hosts for the development of immature stages (Avelar et al., 2015).

Hydrochoeristrema cabrali is thought to be a parasite of the cecum of capybaras (Sinkoc et al., 1998) and was verified through necropsy studies in areas with livestock exploration in the ecological reserve of Taim in Rio Grande do Sul (Sinkoc et al., 2009) and in areas with captive-bred capybaras in the State of São Paulo (Sinkoc et al., 2004), where its occurrence and distribution are restricted.

Taxorchis schistocotyle parasitizes the cecum of capybaras and is an important parasite because of its wide distribution in Brazil and other South American countries (Salas \& Herrera, 2004; Añasco \& Martinez, 2006); it has been identified in necropsy studies conducted in natural areas (Costa \& Catto, 1994; Bonuti et al., 2002), anthropized areas (Avelar et al., 2015) and in captive-bred individuals (Sinkoc et al., 2004).

Although the eggs of parasites belonging to the superfamily Paramphistomoidea have similar morphological characteristics that hinder the identification of the genus of the agents involved in the infection, the digenetic T. schistocotyle is considered the parasite (Paramphistomoidea) most likely to affect capybaras in natural and anthropized areas. The common detection of $T$. schistocotyle in necropsy studies may favor the denomination of this species for eggs with morphological characteristics of the superfamily Paramphistomoidea, which have often been identified in parasitological analyses of feces (Corriale et al., 2011; 2013).

The digenetic $F$. hepatica is not specific to capybaras and can affect several species of domestic and wild animals, including humans, causing great economic losses to livestock (Dracz et al., 2016).

The origin of $F$. hepatica lies in the Old World. This parasite was introduced in America by European colonists through the transport of infected farm animals (Bargues et al., 2017). As capybaras are native to South America, F. hepatica is not considered a natural parasite of capybaras and can establish a nonharmonious parasitic host relationship with acute pathogenicity promoting necro-hemorrhagic cholangiohepatitis, which can cause the death of animals and devastate the group of capybaras in an area (Labruna et al., 2018).

Accidental parasitism appears to be a common occurrence; F. hepatica only occurs in capybaras from anthropized areas, such as public parks (Santarém et al., 2006; El-Kouba et al., 2008; Truppel, 2009; Labruna et al., 2018), or rural areas (Bellato et al., 2009; Dracz et al., 2016) shared with livestock, primarily ruminants. The maintenance of the population of capybaras in isolated natural areas where there is no interaction with the breeding sites of ruminants or access to collections of water contaminated by the waste of these animals could hinder infection.

The biological cycle of $F$. hepatica likely takes place in wetlands, and mollusks of the genus Lymnaea are required as intermediate hosts for the development of immature stages (Dracz et al., 2016). The absence of these mollusks in most areas could inhibit the development of the biological cycle and the occurrence of $F$. hepatica in capybara populations.

Capybaras can be affected by several species of protozoa belonging to the genus Eimeria. Parasitological analyses of capybara feces have identified the species Eimeria capibarae, E. hidrochoeri, E. trinidadensis, E. ichiloensis, E. boliviensis, and E. araside (Casas et al., 1995; Gurgel et al., 2007). These protozoa are specific and occur naturally in capybara populations in various environments across most regions of South America in wild capybaras in natural and anthropized areas (Casas et al., 1995; El-Kouba et al., 2008; Truppel, 2009) as well as in captive capybaras (Gurgel et al., 2007; Reginatto et al., 2008; Albuquerque et al., 2008).

The occurrence of the protozoa Eimeria spp. can vary widely in the capybara population and can be as high as 95 to $100 \%$ of infected animals, both in wild areas under natural circumstances where population densities are not high as well as in areas with higher population densities, such as areas with captive breeding (Casas et al., 1995; Silva et al., 2007; Reginatto et al., 2008). The constant and successive infections occurring throughout the 
life of the animals promote the development of an immune response that can make most adult animals capable of withstanding parasitic infections (Gurgel et al., 2007).

The protozoa Eimeria spp. are much more common in captive-bred individuals and can cause clinical manifestations and death, especially in young animals (Pinheiro et al., 2006). Stress and adverse conditions can decrease the immunity of capybaras and increase the intensity of infection (Pinheiro et al., 2006; Eberhardt et al., 2013).

Few studies have documented the occurrence of Cryptosporidium spp. in capybaras (Meireles et al., 2007; Meireles, 2010). These protozoa are not specific to capybaras and can affect a variety of hosts, including humans and domestic and wild animals (Meireles, 2010; Zahedi et al., 2016). In only one capybara sample from the anthropized area, oocysts with morphological characteristics consistent with Cryptosporidium spp. were observed. The occurrence of Cryptosporidium spp. appears to be related to capybaras coming from anthropized areas, such as places where cattle are reared (Meireles et al., 2007) or in captivity (Reginatto et al., 2008).

Although little is known about the role of capybaras as reservoirs, a molecular study based on the analysis and sequencing of the 18S rRNA and GP60 genes using samples of capybara feces collected on the banks of rivers in the State of São Paulo identified C. parvum zoonotic subtype, suggesting that water reservoirs might be contaminated (Meireles et al., 2007).

Endoparasites considered specific to capybaras are naturally distributed in the population in all of the study areas. Parasitological analyses of stool samples and necropsies have shown that the same endoparasites specific to capybaras are shared by capybaras from natural, anthropized and captive breeding areas (Costa \& Catto, 1994; Bonuti et al., 2002; Sinkoc et al., 2004; Salas \& Herrera, 2004; El-Kouba et al., 2008; Truppel, 2009; Sinkoc et al., 2009).

Although the high population density observed in groups of capybaras in some anthropized areas may contribute to the infection of these animals (Truppel, 2009), significant differences in the frequency of the occurrence of the majority of endoparasites detected in capybaras from natural and anthropized areas were not observed.

Capybaras are considered relatively long-lived animals, but variation in their generations is similar to that observed in small rodents. This property indicates that capybaras show high phenotypic plasticity and genetic variability, which permit them to rapidly respond to environmental changes and might be responsible for their success in anthropized areas (Bovo et al., 2016). This high capacity to adapt to the novel environmental conditions of anthropized areas (Bovo et al., 2016) and their ability to remain gregarious and territorial in anthropized areas as in natural areas (Rodrigues et al., 2013; Almeida et al., 2013) could explain the largely similar pattern of occurrence of capybara-specific endoparasites across the different study areas.

The helminths specific to capybaras appear to be characterized by a dynamic and delicate balance (Pino et al., 2009) that aids the ability of capybaras to withstand the effects of parasitism. Capybaras can develop stressdependent prophylaxis, in which components of their immunity are mobilized to help control the parasitic load of specific helminths (Eberhardt et al., 2013), favoring their adaptation regardless of the habitat in which they occur. In fact, capybaras are considered robust to parasitism, which increases the difficulty of measuring the effects of parasitism on the health of these animals (Salas \& Herrera, 2004; Reginatto et al., 2008). In addition, this property of capybaras facilitates their captive breeding and makes them well adapted for breeding in limited areas (NogueiraFilho \& Nogueira, 2004).

In the capybaras of anthropized areas, a greater number of species of endoparasites was observed, emphasizing that $F$. hepatica and the protozoan Cryptosporidium spp. are not specific parasites of capybaras. Anthropized areas can greatly differ in their environmental conditions compared with natural areas, which could facilitate the contact of capybaras with other animal species, such as ruminants (Meireles et al., 2007; Bellato et al., 2009; Sinkoc et al., 2009) and with the human population (El-Kouba et al., 2008; Truppel, 2009; Labruna et al., 2018), and promote the occurrence of these accidental endoparasites. These parasites have zoonotic potential and can be transmitted through water and food, mainly Cryptosporidium spp. (Santarém et al., 2006; Zahedi et al., 2016). There is thus a need to monitor parasites through coproparasitological examinations of capybaras, that could act as sentinel animals, indicating the presence of these parasites, especially in public parks (Labruna et al., 2018).

\section{Acknowledgments}

This study was supported by Fundação de Amparo à Pesquisa do Estado de São Paulo - FAPESP (process 2013/18046-7) and by Conselho Nacional de Pesquisa e Desenvolvimento Científico e Tecnológico (CNPq) (process 301641/2019-6). 


\section{References}

Albuquerque GR, Berto BP, Catenacci LS, Nogueira SS, Nogueira Filho SLG, Lopes CWG. Eimerid coccidia from capybaras (Hydrochoerus hydrochaeris) in southern Bahia, Brazil. Pesq Vet Bras 2008; 28(7): 323-328. http://dx.doi.org/10.1590/S0100736X2008000700001.

Alho CJR. Criação e manejo de capivaras em pequenas propriedades rurais. Brasília: EMBRAPA-DDT; 1986.

Almeida AMR, Biondi D, Filho ELAM. Dinâmica e biologia de uma população de capivaras em ambiente antrópico, Curitiba-PR. Ciênc Nat 2013; 35(2): 54-64. http://dx.doi.org/10.5902/2179-460X797.

Añasco LG, Martínez FA. Breve descripción de Taxorchis schistocotyle Beddard, 1914 (Trematoda, Cladorchiidae) por microscopia electrónica de barrido. Parasitol Latinoam 2006; 61(3-4): 168-171. http://dx.doi.org/10.4067/S0717-77122006000200012.

Avelar IO, Silva APC, Gardiner C, Santos RL, Lima WS, Ecco R. Pathological and parasitological characterization of infection by trematodes (Paramphistomatidae) in the large intestine of capybaras. Rev Bras Parasitol Vet 2015; 24(3): 345-349. http://dx.doi. org/10.1590/S1984-29612015058. PMid:26444066.

Bargues MD, Gayo V, Sanchis J, Artigas P, Khoubbane M, Birriel S, et al. DNA multigene characterization of Fasciola hepatica and Lymnaea neotropica and its fascioliasis transmission capacity in Uruguay, with historical correlation, human report review and infection risk analysis. PLoS Neg/ Trop Dis 2017; 11(2): e0005352. http://dx.doi.org/10.1371/journal.pntd.0005352. PMid:28158188.

Bellato V, Souza AP, Sartor AA, Neis Veiga LPH, Centenaro F. Ocorrência de Fasciola hepatica na população de capivaras (Hydrochaeris hydrochaeris) e em bovinos (Bos taurus) no município de Timbó, SC, Brasil. Rev Ciênc Agrovet 2009; 8(1): 66-70.

Bonuti MR, Nascimento AA, Mapelli EB, Arantes IG. Helmintos Gastrintestinais de capivaras (Hydrochoerus hydrochaeris) na subregião de Paiaguás, Pantanal do Mato Grosso do Sul, Brasil. Semina: Ciênc Agrár 2002; 23(1): 57-62. http://dx.doi.org/10.5433/1679$0359.2002 v 23 n 1 p 57$.

Bovo AAA, Ferraz KMPMB, Verdade LM, Moreira JR. Capybaras (Hydrochoerus hydrochaeris) in Anthropogenic Environments: Challenges and Conflicts. In: Gheler-Costa C, Lyra-Jorge MC, Verdade LM, editors. Biodiversity in Agricultural Landscapes of Southeastern Brazil. Warsaw, Poland: De Gruyter Open; 2016. p. 178-189. https://doi.org/10.1515/9783110480849-013.

Brandão ML, Chame M, Cordeiro JLP, Chaves SAM. Diversidade de helmintos intestinais em mamíferos silvestres e domésticos na Caatinga do Parque Nacional Serra da Capivara, Sudeste do Piauí, Brasil. Rev Bras Parasitol Vet 2009;18(e1 Suppl1): 19-28. http://dx.doi.org/10.4322/rbpv.018e1004. PMid:20040186.

Casas MC, Duszynski DW, Zalles LM. Three new Eimerians in capybara (Hydrochaeris hydrochaeris) populations from Eastern Bolívia and Southern Venezuela.J Parasitol 1995; 81(2): 247-251. http://dx.doi.org/10.2307/3283928. PMid:7707202.

Corriale MJ, Milano AMF, Gómez-Muñoz MA, Herrera EA. Prevalence of gastrointestinal parasites in a natural population of capybaras, Hydrochoerus hydrochaeris, in Esteros del Iberá (Argentina). Rev Ibero-Latinam Parasitol 2011; 70(2): $189-196$.

Corriale MJ, Orozco MM, Perez IJ. Parámetros poblacionales y estado sanitario de carpinchos (Hydrochoerus hydrochaeris) en lagunas artificiales de los esteros del Iberá. Mastozool Neotrop 2013; 20(1): 31-45.

Costa CAF, Catto JB. Helmintos parasitos de capivaras (Hydrochaeris hydrochaeris) na sub-região de Nhecolândia, Pantanal Sulmatogrossensse. Rev Bras Biol 1994; 54(1): 39-48. PMid:8209035.

Dracz RM, Ribeiro VMA, Pereira CAJ, Lima WS. Occurrence of Fasciola hepatica (Linnaeus, 1758) in capybara (Hydrochoerus hydrochaeris) (Linnaeus, 1766) in Minas Gerais, Brazil. Rev Bras Parasitol Vet 2016; 25(3): 364-367. http://dx.doi.org/10.1590/ S1984-29612016021. PMid:27096531.

Eberhardt AT, Costa SA, Marini MR, Racca A, Baldi CJ, Robles R, et al. Parasitism and Physiological Trade-Offs in Stressed Capybaras. PLoS One 2013; 8(7): e70382. http://dx.doi.org/10.1371/journal.pone.0070382. PMid:23894644.

El-Kouba MMAN, Marques SMT, Pilati C, Hamann W. Aspectos gerais da fasciolose de endoparasitoses em capivaras (Hydrochaeris hydrochaeris Linnaeus, 1766) de três parques no Paraná, Brasil. Vet Foco 2008; 6(1): 4-15.

Faust EC. Notes on helminths from Panama. I. Taxorchis schistocotyle (Fischoeder, 1901) from the Panamanian capybara, Hydrochoerus isthmius Goldman, 1912. J Parasitol 1935; 21(5): 323-331. http://dx.doi.org/10.2307/3271941.

Ferreira LF, Morteo RE, Silva JR. Padronização de técnicas para o exame parasitológico das fezes. J Bras Med 1962; 6(2): 242-257.

Gioia-di Chiacchio R, Prioste FES, Vanstreels RET, Knöbl T, Kolber M, Miyashiro SI, et al. Health evaluation and survey of zoonotic pathogens in free-ranging capybaras (Hydrochoerus hydrochaeris). J Wildl Dis 2014; 50(3): 496-504. http://dx.doi.org/10.7589/201305-109. PMid:24779462.

Gurgel APF, Sartori AS, Araújo FAP. Eimeriosis in capybaras (Hydrochaeris hydrochaeris) in the State of Rio Grande do Sul, Brazil. Parasitol Latinoam 2007; 62(1-2): 76-78. http://dx.doi.org/10.4067/S0717-77122007000100013.

Labruna MB, Costa FB, Port-Carvalho M, Oliveira AS, Souza SLP, Castro MB. Lethal Fascioliasis in Capybaras (Hydrochoerus hydrochaeris) in Brazil. J Parasito/ 2018; 104(2): 173-176. http://dx.doi.org/10.1645/17-114. PMid:29185852. 
Luz HR, Costa FB, Benatti HR, Ramos VN, Serpa MCA, Martins TF, et al. Epidemiology of capybara-associated Brazilian spotted fever. PLoS Neg/ Trop Dis 2019; 13(9): e0007734. http://dx.doi.org/10.1371/journal.pntd.0007734. PMid:31490924.

Meireles MV, Soares RM, Bonello F, Gennari SM. Natural infection with zoonotic subtype of Cryptosporidium parvum in Capybara (Hydrochoerus hydrochaeris) from Brazil. Vet Parasitol 2007; 147(1-2): 166-170. http://dx.doi.org/10.1016/j.vetpar.2007.03.034. PMid:17467175.

Meireles MV. Cryptosporidium infection in Brazil: implications for veterinary medicine and public health. Rev Bras Parasito/ Vet 2010; 19(4): 197-204. http://dx.doi.org/10.1590/S1984-29612010000400002. PMid:21184694.

Monteiro SG. Parasitologia na Medicina Veterinária. São Paulo: Roca; 2011.

Muñoz K, Chávez A. Trypanosoma evansi isolated from capybara (Hidrochaeris hidrochaeris). Mem Inst Oswaldo Cruz 2001; 96(7): 945-946. http://dx.doi.org/10.1590/S0074-02762001000700009. PMid:11685258.

Nogueira-Filho SLG, Nogueira SSC. Captive breeding programs as an alternative for wildlife conservation in Brazil. In: Silvius KM, Bodmer RE, Fragoso JMV, editors. People in Nature: Wildlife Manegement and Conservation in South and Central America. New York: Columbia University Press; 2004. p. 171-190. http://dx.doi.org/10.7312/silv12782-011

Ogassawara S, Benassi S. Infecção experimental de gatos com coração de bovino parasitado por Sarcocystis sp. Arq Inst Biol (Sao Paulo) 1980; 47(1-2): 27-32.

Pinheiro MS, Wendt LW, Garcia CAN, Sinkoc AL, Ruas J. Controle da mortalidade por parasitismo gastrointestinal em filhotes de capivara (Hydrochaeris hydrochaeris) criados em sistema semi-intensivo. Comunicado Técnico 148. Pelotas: Embrapa Clima Temperado; 2006.

Pino MS, Santa Cruz A, Comolli J, Sarmiento N, Acuña M, Roux JP, et al. Aspectos morfológicos de Protozoophaga obesa en carpincho (Hydrochoerus hydrochaeris), en cautiverio. Mercedes, Corrientes, Argentina. Rev Med Vet (B Aires) 2009; 90(5-6): 92-95.

Polo G, Acosta CM, Labruna MB, Ferreira F, Brockmann D. Hosts mobility and spatial spread of Rickettsia rickettsii. PLOS Comput Biol 2018; 14(12): e1006636. http://dx.doi.org/10.1371/journal.pcbi.1006636. PMid:30586381.

Reginatto AR, Farret MH, Fanfa VR, Silva AS, Monteiro SG. Infecção por Giardia spp. e Cystoisospora spp. em capivara e cutia no sul do Brasil. RPCV 2008; 103(565-566): 96-99.

Rego AA. Revisão do gênero Monoecocestus Bessard, 1914: (Cestoda, Anoplocephalidae). Mem Inst Oswaldo Cruz 1961; 59(3): 325-354. http://dx.doi.org/10.1590/S0074-02761961000300006. PMid:14491094.

Ribeiro KT, Rocha GFS, Saraiva DG, Silva AP, Vilela DAR, Lima PCS, et al. Das capivaras e carrapatos a uma proposta de comunicação e manejo no Parque Nacional da serra do Cipó para redução de riscos à saúde. Oecol Aust 2010; 14(3): 668-685. http://dx.doi. org/10.4257/oeco.2010.1403.05.

Ribeiro SMB, Amato SB. Estratégia de infecção de Protozoophaga obesa (Diesing, 1851) Travassos, 1923 (Oxyuroidea, Oxyuridae). Arq Inst Biol (Sao Paulo) 2003; 70(2): 131-133.

Rodrigues MV, Paula TAR, Ferreira LBC, Ávila EC, Silva LC, Souza VB. Comportamento de um grupo de capivaras em área urbanizada. Acta Vet Bras 2013; 7(3): 212-217. http://dx.doi.org/10.21708/avb.2013.7.3.3142.

Salas V, Herrera EA. Intestinal helminths of capybaras, Hydrochoerus hydrochaeris, from Venezuela. Mem Inst Oswaldo Cruz 2004; 99(6): 563-566. http://dx.doi.org/10.1590/S0074-02762004000600004. PMid:15558163.

Santarém VA, Tostes RA, Alberti H, Sanches OC. Fasciola hepatica in capybara. Acta Trop 2006; 98(3): 311-313. http://dx.doi. org/10.1016/j.actatropica.2006.05.004. PMid:16774732.

Santos FGA, Zamora LM, Fonseca FCE, Ribeiro VMF. Controle de parasitas intestinais de capivaras (Hydrochoerus hydrochaeris) criadas em sistema semi-extensivo, no município de Senador Guimard Santos, Acre. Acta Vet Bras 2011; 5(4): 393-398. http:// dx.doi.org/10.21708/avb.2011.5.4.2637.

Silva MK, Silva AS, Oliveira CB, Soares JF, Monteiro SG. Ocorrência de Eimeria ichiloensis em capivaras (Hydrochaeris hydrochaeris) de criatório. Arq Ciênc Vet Zool 2007; 10(2): 129-131.

Sinkoc AL, Brum FA, Muller G, Brum JGW. Helmintos parasitos de capivara (Hydrochoerus hydrochaeris L. 1766) na região de Araçatuba, São Paulo, Brasil. Arq Inst Biol (Sao Paulo) 2004; 71(3): 329-333.

Sinkoc AL, Brum JGW, Muller G. Gastrintestinal Helminths of Capybara (Hydrochoerus hydrochaeris, Linnaeus, 1766) in Cattle Breeding Farm in the Area of the Ecological Reserve of Taim, Rio Grande. Braz Arch Biol Technol 2009; 52(2): 327-333. http:// dx.doi.org/10.1590/S1516-89132009000200009.

Sinkoc AL, Muller G, Brum JGW. Hydrochoeristrema cabrali n.g. n. sp. (Trematoda: Paramphistomidae: Cladorchiini) parasito de capivara (Hydrochoerus hydrochaeris Linnaeus, 1766) (Rodentia: Hydrochoeridae). Arq Inst Biol (Sao Paulo) 1998; 65(1): 115-118.

Solórzano-García B, Pérez-Ponce de León G. Helminth parasites of howler and spider monkeys in Mexico: insights into molecular diagnostic methods and their importance for zoonotic diseases and host conservation. Int J Parasitol Parasites Wildl 2017; 6(2): 76-84. http://dx.doi.org/10.1016/j.ijppaw.2017.04.001. PMid:28462089. 
Souza CE, Moraes-Filho J, Ogrzewalska M, Uchoa FC, Horta MC, Souza SL, et al. Experimental infection of capybaras Hydrochoerus hydrochaeris by Rickettsia rickettsii and evaluation of the transmission of the infection to ticks Amblyomma cajennense. Vet Parasitol 2009; 161(1-2): 116-121. http://dx.doi.org/10.1016/j.vetpar.2008.12.010. PMid:19147293.

Tantaleán VM, Angulo TJ, Quispe HM, Díaz MS. Morphological differentiation of eggs from three trematode species in ruminants from Peru. Peruv J Parasitol 2012; 20(2): e78-e82.

Thienpont D, Rochette F, Vanparijs OFJ. Diagnosing Helminthiasis Trough Coprological Examination. Beerse, Belgium: Jansssen Animal Health; 2003.

Truppel JH. Avaliação do parasitismo em capivaras (Hydrochaeris hydrochaeris) e sua atuação como hospedeiro intermediário de Neospora caninum e Toxoplasma gondii. [dissertação]. Curitiba: Universidade Federal do Paraná; 2009.

Valadas S, Gennari SM, Yai LEO, Rosypal AC, Lindsay DS. Prevalence of antibodies to Trypanosoma cruzi, Leishmania infantum, Encephalitozoon cuniculi, Sarcocystis neurona, and Neospora caninum in capybara, Hydrochoerus hydrochaeris, from São Paulo State, Brazil. J Parasitol 2010; 96(3): 521-524. http://dx.doi.org/10.1645/GE-2368.1. PMid:20020808.

Vargas FC, Vargas SC, Moro MEG, Silva V, Carrer CRO. Monitoramento populacional de capivaras (Hydrochaeris hydrochaeris Linneus, 1766) em Pirassununga, SP, Brasil. Cienc Rural 2007; 37(4): 1104-1108. http://dx.doi.org/10.1590/S0103-84782007000400030.

Vieira FM, Lima SS, Bessa ECA. Morfologia e biometria de ovos e larvas de Strongyloides sp. Grassi, 1879 (Rhabditoidea: Strongyloididae) parasito gastrointestinal de Hydrochaeris hydrochaeris (Linnaeus, 1766) (Rodentia: Hydrochaeridae), no município de Juiz de Fora, Minas Gerais. Rev Bras Parasitol Vet 2006; 15(1): 7-12. PMid:16646995.

Yai LE, Ragozo AM, Soares RM, Pena HF, Su C, Gennari SM. Genetic diversity among capybara (Hydrochaeris hydrochaeris) isolates of Toxoplasma gondii from Brazil. Vet Parasitol 2009; 162(3-4): 332-337. http://dx.doi.org/10.1016/j.vetpar.2009.03.007. PMid:19375864.

Zahedi A, Paparini A, Jian F, Robertson I, Ryan U. Public health significance of zoonotic Cryptosporidium species in wildlife: critical insights into better drinking water management. Int J Parasitol Parasites Wildl 2016; 5(1): 88-109. http://dx.doi.org/10.1016/j. ijppaw.2015.12.001. PMid:28560163. 